\title{
Upaya Pencegahan Financial Distress Melalui Pelatihan Manajemen Kas Keuangan Keluarga
}

\author{
Yulida Army Nurcahya ${ }^{1}$ \\ Universitas Tidar, yulidaarmy@untidar.ac.id \\ Octavia Lhaksmi Pramudyastuti ${ }^{2}$ \\ Universitas Tidar, octaviaovi@gmail.com \\ Fitrah Sari Islami ${ }^{3}$ \\ Universitas Tidar , fitrahsariislami21@gmail.com \\ Azizah $^{4}$ \\ Universitas Tidar, azizahzizah39@gmail.com \\ Rizky Puspita Dewi ${ }^{5}$ \\ Universitas Tidar, riskypuspita2015@gmail.com
}

\begin{abstract}
Abstrak
Membangun rumah tidak hanya diperlukan tangggungjawab, tetapi dibutuhkan rasa percaya antara seorang suami dengan istri. Suami tidak hanya menjadi kepala keluarga tetapi ia bertanggung jawab atas pemenuhan kebutuhan dalam rumah tangganya, akan tetapi minimnya pengetahuan para ibu rumah tangga dalam mengelola keuangan keluarga bisa menyebabkan terjadinya financial distress. Salah satu indikator terjadinya financial distress dalam keuangan keluarga adalah dimana pengeluaran lebih besar dibandingkan pendapatan sehingga mengakibatkan keluarga tersebut sering berhutang atau dalam peribahasa menyebutkan gali lobang tutup lobang. Selain itu titik kelemahan lainnya adalah salah satunya tidak dapat membedakan antara kebutuhan dan keinginan. Dengan latar belakang tersebut menjadi pertimbangan kami Tim Pengabdian Universitas Tidar untuk melakukan pelatihan kepada para ibu-ibu PKK di Desa Semirejo 1 Kecamatan Tempuran Kabupaten Magelang untuk dapat mengelola keuangan keluarga dengan tepat. Pelatihan manajemen kas keuangan rumah tangga ini memiliki tujuan agar para peserta mampu mengatur keuangan rumah tangga dengan baik dan mencegah terjadinya financial distress atau kebangkrutan, Selain itu diharapkan peserta dapat membedakan antara kebutuhan dan keinginan. Metode yang kami lakukan adalah memberikan pelatihan pada saat pertemuan bulanan ibu-ibu PKK, dengan metode ceramah dan membagikan kuisioner. Hasil pencapaian dari pelatihan ini terlihat bahwasannya ibu-ibu PKK semakin sadar akan pentingnya kebutuhan dalam rumah tangga itu lebih penting dibandingkan dengan keinginan sesaat. Dalam pelatihan ini ibu-ibu PKK tidak hanya mendapatkan pengetahuan tetapi juga kesadaran terhadap perencanaan keuangan keluarga di masa mendatang.
\end{abstract}

Kata Kunci: Manajemen, Kas, Keuangan, Keluarga, Financial distress

\section{Abstract}

Building a house not only requires responsibility, but it takes trust between a husband and wife. The husband is not only the head of the family but he is responsible for meeting the needs 
in the household. Not only that, but the lack of knowledge of housewives in managing family finances can cause financial distress. One indicator of the occurrence of financial distress in family finances is where expenditure is greater than income, resulting in the family often in debt or in proverbs mentioning digging holes. Besides that, another weak point is that one of them cannot distinguish between needs and desires. With this background, it is our consideration for the Tidar University Dedication Team to conduct training for PKK women in Semirejo Village 1, Tempuran District, Magelang Regency to be able to manage family finances appropriately. The training on household cash management has the objective so that participants are able to manage household finances well and prevent financial distress or bankruptcy. In addition, participants are expected to be able to distinguish between needs and desires. Our method is to provide training at monthly meetings of PKK mothers, using the lecture method and distributing questionnaires. The results of this training show that PKK women are increasingly aware of the importance of needs in the household compared to momentary desires. In this training PKK mothers not only gain knowledge but also awareness of family financial planning in the future.

\section{Keywords: Management, Cash, Finance, Family, Financial distress}

\section{Pendahuluan}

Permasalahan dalam keuangan sering kali menjadi salah satu ancaman bagi goyahnya rumah tangga. Sudah menjadi tradisi bahwa seorang istri yang akan mengatur keuangan dalam rumah tangga. Tetapi bukan hanya tugas seoang istri saja dalam mengelola keuangan rumah tangga, dibutuhkan keterbukaan antara suami dan istri agar keduanya tidak saling curiga dan keduanya harus saling percaya dan jujur dalam hal apapun itu. Namun pengelolaan keuangan sering kali dianggap gampang dan sering kali di abaikan. Tetapi dalam realitanya pengelolaan keuangan menjadi salah satu masalah besar dalam sebuah rumah tangga. Sering kali seseorang tidak bisa membedakan antara keinginan dan kebutuhannya. Kebutuhan itu sendiri adalah suatu yang dibutuhkan manusia agar dirinya merasa sejahtera, jika kebutuhan tersebut tidak terpenuhi maka anggapan tidak sejahtera akan dilontarkan. Sedangkan keinginan adalah suatu hal yang diharapkan bisa terlaksana, sehingga seseorang merasa dirinya puas. Namun, yang kita ketahui adalah manusia itu tidak pernah puas. Anggapan tersebut adalah umum dikalangan manusia. Tidak sedkit yang mengganggap perencanaan keuangan itu sepele, namun ketika dihadapkan pada kebutuhan yang harus dipenuhi dengan keuangan yang berbanding terbalik, perencanaan keuangan menjadi hal yang sangat penting. Hal ini dikarenakan kurang mampu dalam mengelola keuangan. Maka karena adanya hal tersebut, dalam menjalankan kehidupan rumah tangga diperlukan manajemen keuangan atau manajemen kas dalam menjalankan pengelolaan keuangan dalam kehidupan keluarga. Manajemen berarti proses,manajemen kas memiliki peranan penting dalam mengatur pengeluaran dan pemasukan kas lebih tepatnya mengatur dalam pendapatan yang adadengan kebutuhan yang harus dipenuhi. Pengeluaran merupakan faktor penting dalam manajemen kas. Tanpa kita sadari masalah pengaturan keuangan dialami oleh semua kalangan masyarakat baik masyarakat yang tergolong miskin, dan kaya.serta untuk memperkecil risiko yang akan terjadi 
dikemudian hari, termasuk meminimalisir biaya yang dianggap tidak efesien yang mengkin akan timbul saat memenuhi kebutuhan. Selain itu, dengan adanya manajemen kas kita bisa melakuaan perencanaan untuk target atau prioritas yang ingin dicapai. Siapa pun bisa mengatur keuangan keluarganya. Namun, pada umumnya istri bertanggung jawab pada pengelolaan keuangan keluarga. Jika telah bisa mengelola keuangan keluarganya maka bisa dikatakan $50 \%$ mereka sudah sukses dan berhasil dalam hal finansialnya. Sehingga dapat memenuhi kebutuhan dan mencapai keinginan yang diinginkan sehingga mencapai kepuasan.

Menurut OJK bahwa Perencanaan keuangan adalah seni pengelolaan keuangan yang dilakukan oleh individu atau keluarga untuk mencapai tujuan yang efektif, efisien, dan bermanfaat. Sehingga, keluarga tersebut menjadi sejahtera, kuat, dan mandiri. Aktivitas yang dilakukan ini adalah proses pengelolaan pendapatan untuk mencapai tujuan finansial seperti keinginan mengumpulkan dana atau memiliki tabungan untuk keinginan atau kebutuhan di masa yang akan datang. Melalui manajemen keuangan, kita akan belajar cara pengambilan keputusan berdasarkan skala prioritas sesuai dengan kondisi perekonomian keluarga. Kita dapat memprioritaskankan kebutuhan yang sangat penting, penting, dan kurang penting, sehingga ada sisa uang yang bisa ditabung dan digunakan untuk memenuhi kebutuhan atau keinginan di masa yang akan datang. Dengan pengelolaan keuangan yang baik, maka uang yang terbatas dapat dikendalikan penggunaanya, sehingga akan membawa kesejahteraan keluarga. Bagi keluarga. Tak hanya keluarga dengan pendapat pas-pasan, hal ini juga berpengaruh pada keluarga bercukupan atau setiap keluarga yang ada. Manajemen keuangan mampu menekan keinginan seseorang untuk terpenuhi hal ini akan berpengaruh pada kehidupan di masa mendatang keluarga tersebut.

Penelitian yang dilakukan oleh Fuaida (2009) mengenai manajemen keuangan keluarga miskin, studi kasus mitra program masyarakat mandiri, dompet dhuafa Republika, ditemukan bahwa adanya perbedaan pendapatan, tingkat kemampuan dan kemandirian keluarga dalam hal mengelola keuangan di setiap keluarga mitra program masyarakat mandiri, dompet dhuafa Republika di Bogor, Tangerang dan Bekasi,baik dari segi input, troughput dan output. Dikatakan bahwa kemampuan dan kemandirian seseorang dirasa sangat penting dalam mengelola keuangan karena dengan memiliki kemampuan dan kemandirian dalam mengelola keuangan menumbuhkan sikap pola hidup hemat, menghindarkan diri dari utang, semua kebutuhan dapat terencana dengan detail, mengurangi stress, memiliki perencanaan yang lebih baik di masa yang akan datang, dan kita dapat menyisihkan uang untuk bersedekah. Dengan bersedekah tidak membuat uang kita berkurang, namun membuat kita lebih bahagia. Manajemen kas membantu seseorang untuk mengutamakan kebutuhan yang wajib terpenuhi terlebih dahulu. Jika semua kewajiban itu terpenuhi, baru digunakan dalam kehidupan sehari-hari.

Perilaku keuangan indonesia cenderung konsumtif, kemudian menimbulkan berbagai perilaku keuangan yang tidak bertanggung wajab. Menurut otoritas jasa keuangan (OJK) mengatakan masyarakat indonesia menjadi lebih konsumtif dan meninggalkan kebiasaan menabung hal ini terlihat pada MPS dan MPC 5 tahun terakhir ini.

Dalam Yulianti dan Silvy (2013) Hilgret \& Jeanne menyatakan bahwa keputusan keuangan yang baik dan benar dibutuhkan untuk meningkatkan pendapatan, 
mengelola pengeluaran, pembayaran pajak agar manajemen keuangan keluarga menjadi baik. Pengalaman yang positif di lingkungan sosial, pengelolaan keuangan dan sikap menghemat akan berpengaruh terhadap kehidupan keluarga yang akan kita jalani nantinya. Motivasi individu untuk hidup lebih baik dengan belajar dari pengalaman. Pengalaman tidak hanya dipelajari berdasarkan pengalaman pribadi tetapi juga dapat dipelajari berdasarkan pengalaman dari keluarga ataupun teman sehingga kita bisa belajar untuk mengambil keputusan secara hati-hati dan mengetahui cara pengelolaan keuangan yang baik, sehingga dapat melakukan perencanaan di masa yang akan datang. Dengan pengalaman kita bisa tahu mana yang baik dan tidak, kita tidak akan mengulangi kesalahan yang sama, terutama dalam hal keuangan.

Dalam Andrew dan Linawati (2014) Hilgert et al menyatakan bahwa personal income adalah total pendapatan kotor dari seorang individu berasa dari upah atau gaji dari perusahaan bisnis dan berbagai investasi. Personal income adalah penghasilan pribadi sebelum pajak. Personal income diukur berdasarkan pendapatan dari semua sumber. Komponen terbesar dari total pendapatan adalah upah dan gaji. Selain itu, ada banyak kategori lain pendapatan, termasuk pendapatan sewa, pembayaran subsidi pemerintah, pendapatan bunga dan pendapatan dividen. Personal income adalah indikator yang baik untuk permintaan konsumen masa depan meskipun tidak sempurna. Pendapatan yang didapat terkadang tidak sesuai dengan kebutuhan yang harus dipenuhi, tak heran jika seseorang sulit untuk melakukan perencanaan keuangan. Namun, hal tersebut tidak bisa dijadikan suatu permasalahan, karena biasanya dengan keterbatasan ekonomi menjadikan diri seseorang ntuk lebih produktif daripada merenungkan sesuatu yang tidak berubah jika kita hanya merenungkannya saja. Perencanaa keuangan dibutuhkan untuk mengetahui bagaimana cara terbaik untuk mengelola keuangan dan membedakan antar kebutuhan dan keinginan yang tidak terlalu dibutuhkan pada masa itu. Namun, ketika kebutuhan sudah terpebuhi keinginan menjadi suatu hal yang akan dipenuhi oleh seseorang untuk menghasilkan kepuasan.

Tulisan ini mencoba membahas lebih dalam mengenai teknik pengelolaan keuangan rumah tangga yang baik dilihat dari sisi manajemen keuangan, dengan harapan dapat memberikan masukan untuk memecahkan masalah keuangan yang dihadapi dalam keluarga, meminimalisir terjadinya risiko di kemudian hari, meminimalisir terjadinya biaya tidak efisien yang akan muncul ketika dihadapkan pada keinginan dan kebutuhan yang harus dipenuhi. Mampu memberikan keyakinan kepada keluarga untuk bisa hidup hemat, kemungkinan target di kemudian hari akan mudah dicapai. Sifat boros seseorang adalah salah satu masalah utama dalam keuangan keluarga. Dibutuhkan perencanaan yang baik untuk mengelola keuangan keluarga sehingga kebutuhan dapat terpenuhi dengan baik dan keinginan dapat dengan mudah dicapai.

Tim pemberdayaan dan kesejahteraan keluarga (PKK) adalah institusi resmi dalam suatu desa yang beranggotakan ibu-ibu rumah tangga, yang bertujuan sebagai penggerak terwujudnya kesejahteraan keluarga, kuat, dan mandiri lahir batin. Mitra kami yang terlibat adalah warga Desa Semirejo 1, Kecamatan Tempuran. Permasalahan yang dihadapi oleh mitra secara khusus adalah sebagai berikut: 1) Ibu- 
ibu tidak dapat membedakan antara kebutuhan dan keinginan. 2) Minimnya pengetahuan tentang konsep manajemen kas keuangan keluarga yang terencana. Maka dari itu kami memberikan motivasi dan semangat kepada ibu-ibu pentingnya manajemen kas keuangan pada rumah tangga. Dengan cara memberikan materi tentang teori bagaimana menyusun rencana keuangan rumah tanggayang baik dan benar. Selain itu, kami memberikan kuisioner mengenai financial behavior dan financial attitude dimana kami bisa mengukur bagaimana kesadaran ibu-ibu PKK terhadap perencanaan keuangan keluarga agar mencegah terjadinya (Financial Distress). Attitude keuangan atau financial attitude yang dimiliki oleh seseorang akan membantu individu tersebut dalam menentukan sikap dan berperilaku mereka dalam hal keuangan, baik dalam hal pengelolaan keuangan, penganggaran keuangan pribadi, atau bagaimana keputusan individu mengenai bentuk investasi yang akan diambil. Behavior finance adalah suatu perilaku yang berkaitan dengan aplikasi keuangan. Menurut Ricciardi (2000), behavioral finance adalah suatu displin ilmu yang di dalamnya melekat interaksi berbagai displin ilmu dan secara terus menerus berintegrasi sehingga pembahasannya tidak dilakukan isolasi. 3 aspek yang mempengaruhi financial behavior seseorang adalah psikologi, sosiologi, dan keuangan. Seseorang yang ingin mempelajari perilaku keuangan harus memiliki pengertian mengenai aspek psikologi, sosiologi, dan keuangan. Financial distress yang dimaksud di sini adalah kondisi keuangan keluarga berada dalam masalah. Ditandai dengan tidak bisa terpenuhinya kebutuhan yang harus dipenuhi. Penyebabnya adalah ketika seseorang tidak bisa mengalokasikan pendapatan sesuai dengan kebutuhan, dan tidak bisa membedakan antara keinginan dan kebutuhan yang harus dipenuhi.

Pengetahuan keuangan pada saat ini sangat diperlukan karena masyarakat pada saat ini lebih mementingkan keinginan daripada kebutuhannya.

\section{Metode}

Dalam kegiatan ini, pelaksanaan dilakukan selama 2 (dua) kali pada bulan Juli dan September, pukul 15.00-17.30 bertempatan di Rumah warga Desa Semirejo 1 Kecamatan Tempuran Kabupaten Magelang, dengan tahapan-tahapan yang dilaksanakan yaitu:

1. Memberikan pengetahuan mengenai financial distress beserta pencegahannya. Pemberian materi ini bertujuan agar peserta mampu memahami indikatorindikator apa saja yang dapat menyebabkan financial distress dalam rumah tangga masing-masing. Dengan adanya materi tersebut menambah pengetahuan para peserta mengenai apa itu financial distress.

2. Memberikan wawasan mengenai pentingnya manajemen cash flow dan tips mengatur keuangan secara baik dan benar. Hal ini bertujuan untuk mencegah terjadinya financial distress serta memberikan gambaran perencanaan jangka panjang.

3. Membagikan kuisioner mengenai financial behavior dan financial attitude agar dapat mengukur bagaimana kesadaran para peserta dalam mengelola keuangan rumah tangga masing-masing. Kami mengolah data kuisioner dengan aplikasi spss.

Dalam Kegiatan Pelatihan ini partisipasi mitra berupa antara lain: 
1. Kehadiran ibu-ibu PKK dalam kegiatan pelatihan pengelolaan manajemen kas

2. Mengisi kuisioner yang sudah diberikan kepada ibu-ibu PKK

3. Keaktifan peserta ibu-ibu PKK dalam melakukan konsultasi

4. Peserta ibu-ibu PKK praktik langsung membuat catatan perencanaan keuangan rumah tangga

Kegiatan Pengabdian ini dikatakan berhasil jika peserta ibu-ibu PKK Desa Semirejo 1 Kecamatan Tempuran sudah mulai memahami pentingnya perencanaan manajemen kas keuangan keluarga dan sudah bisa membedakan antara kebutuhan dan keinginan.

\section{Hasil dan Pembahasan}

Pemahaman peserta ibu-ibu PKK terhadap perencanaan pengelolaan keuangan rumah tangga diperoleh dari pemateri. Tingkat kesadaran dari ibu-ibu PKK sudah terbentuk hingga terlihat pada keaktifan dan antusiasme peserta dalam berdiskusi. Mereka sangat aktif bertanya bagaimana cara perencanaan keuangan rumah tangga yang baik dan benar. Selain itu, peserta ibu-ibu PKK mampu membuat rencana keuangan rumah tangga yang disusun berdasarkan materi pelatihan manajemen kas dalam rumah tangga. Materi tersebut disampaikan untuk memberi konsep terhadap perencanaan keuangan dalam rumah tangga. Mayoritas dari mereka sudah mempunyai rencana pengelolaan keuangan rumah tangga. Namun, pada realitanya masih terdapat istilah besar pasak daripada tiang. Pengeluaran yang terjadi lebih banyak daripada pemasukan pendapatan dalam keuangan rumah tangga. Tidak bisa membedakan anatara keinginan dan kebutuhan yang harus dipenuhi. Maka dari itu kami memberikan tips-tips bagaimana perencanaan keuangan rumah tangga agar efektif dan efisien. Sehingga, ibu-ibu PKK bisa mengelola keuangannya dengan baik, membedakan antara kebutuhan dan keinginan dan dapat menggunakan pendaatan untuk pengeluaran seminimal mungkin tetapi dengan kebutuhan semaksimal mungkin. Terakhir, peserta ibu-ibu PKK kami berikan kuisioner mengenai financial behavior (tingkah laku) dan financial attitude (sikap) berikut output yang dihasilkan. Financial behavior pada dasarnya bertujuan agar seseorang mengambil keputusan dalm keuangan mereka. Financial management behavior seseorang dapat dilihat dari beberapa yaitu konsumsi, cash flow management, saving and investment dan credit management. Financial management behavior seseorang dapat dilihat dari empat hal (Dew dan Xiao, 2011) yaitu :

1. Consumption (Konsumsi), adalah pengeluaran oleh rumah tangga atas berbagai barang dan jasa (Mankiw, 2003). Financial management behavior seseorang dapat dilihat dari bagaimana ia melakukan kegiatan konsumsinya seperti apa yang di beli seseorang dan mengapa ia membelinya (Ida dan Dwinta,2010).

2. Cash-flow management (Arus kas) adalah indikator utama dari kesehatan keuangan yaitu ukuran kemampuan seseorang untuk membayar segala biaya yang dimilikinya, manajemen arus kas yang baik adalah tindakan penyeimbangan, masukan uang tunai dan pengeluaran. Cash flow management dapat diukur dari apakah seseorang membayar tagihan tepat waktu, memperhatikan catatan atau bukti pembayaran dan membuat anggaran keuangan dan perencanaan masa depan (Hilgert dan Hogarth, 2003). 
3. Saving and investment Tabungan dapat didefinisikan sebagai bagian dari pendapatan yang tidak dikonsumsi dalam periode tertentu. Karena seseorangtidak tahuapa yang akan terjadidi masa depan, uang harusdisimpanuntuk membayarkejadian tak terduga.Investasi, yakni mengalokasikan atau menanamkan sumberdaya saat ini dengan tujuan mendapatkan manfaat di masa mendatang (Henry, 2009).

4. Credit management (manajemen utang). Manajemen utang adalah kemampuan seseorang dalam memanfaatkan utang agar tidak membuat anda mengalami kebangkrutan, atau dengan lain kata yaitu atau pemanfaatan utang untuk meningkatkan kesejahteraannya (Sina, 2014).

Financial atitude sangat mempengaruhi financial behavior. Financial atitude sendiri adalah pendapat atau penilaian mengenai keuangan. Jadi dapat diartikan bahwa sikap seseorang mengacu bagaimana mereka merasa keuangan dapat diukur dengan sebuah pernyataan atau pendapat, financial atitude akan membantu seseorang dalam menentukan sikap dan perilaku individu baik dalam mengelola keuangn, melakukan penganggaran keuangan, dan mengambil keputusan keuangan dalam rumah tangga. Jika seorang individu berada dilingkungan pengelolaan keuangan yang baik maka individu tersebut akan mengelola keuangan dengan baik pula. Sikap mengacu pada bagaiman seorang individu atau rumah tangga merasa tentang masalah keuangan pribadi, yang diukur dengan pernyataan atau tanggapan atas sebuath pendapat atau opini. Financial management behavior mengacu pada bagaimana seseorang berprilaku dengan keuangan pribadi, yang diukur dengan tindakan individu tersebut. Terdapat suatu hubungan antara financial attitudes dan tingkat masalah keuangan. Dengan demikian dapat dikatakan bahwa sikap keuangan seseorang juga berpengaruh terhadap cara seseorang mengatur perilaku keuangannya. Sejumlah financial attitudes juga terkait dengan kesulitan keuangan yang seringkali dihadapi oleh berbagai kalangan termasuk didalamnya kehidupan rumah tangga. Sikap keuangan berpengaruh terhadap financial management behavior.

Financial attitudes dapat dicerminkan oleh enam konsep berikut (Furnham,1984), yaitu: 1 . Obsession,merujuk pada pola pikir seseorang tentang uang dan persepsinya tentang masa depan untuk mengelola uang dengan baik. 2. Power, yaitu merujuk pada seseorang yang menggunakan uang sebagai alat untuk mengendalikan orang lain dan menurutnya uang dapat menyelesaikan masalah. 3. Effort, merujuk pada seseorang yang merasa pantas memiliki uang dari apa yang sudah dikerjakannya. 4 . Inadequacy, merujuk pada seseorang yang selalu merasa tidak cukup memiliki uang 5. Retention, merujuk pada seseorang yang memiliki kecenderungan tidak ingin menghabiskan uang 6. Security, merujuk pada pandangan seseorang yang sangat kuno tentang uang seperti anggapan bahwa uang lebih baik hanya disimpan sendiri tanpa ditabung di Bank atau untuk investasi.

Kesimpulannya adalah koefisien korelasi sebesar 0,568 menunjukkan bahwa keeratan hubungan antara financial behavior (tingkah laku) dengan financial attitude (sikap) sebesar 0,568 atau 56,8 persen. Korelasi antara financial behavior (tingkah laku) dengan financial attitude (sikap) bernilai positif berarti hubungan tersebut searah. 
Tabel 1. Koefisien korelasi

\begin{tabular}{|c|c|c|c|}
\hline \multicolumn{4}{|c|}{ Correlations } \\
\hline & & $\begin{array}{c}\text { JUMLAH_B } \\
\text { EHAVIOR }\end{array}$ & $\begin{array}{l}\text { JUMLAH_A } \\
\text { TTITUDE }\end{array}$ \\
\hline \multirow{4}{*}{$\begin{array}{l}\text { JUMLAH_BEHA } \\
\text { VIOR }\end{array}$} & Pearson & 1 &, $568^{* *}$ \\
\hline & Correlation & & \\
\hline & Sig. (2-tailed) & & 001 \\
\hline & $\mathrm{N}$ & 30 & 30 \\
\hline \multirow{4}{*}{$\begin{array}{l}\text { JUMLAH_ATTIT } \\
\text { UDE }\end{array}$} & Pearson & $568^{* *}$ & 1 \\
\hline & Correlation & & \\
\hline & Sig. (2-tailed) & 001 & \\
\hline & $\mathrm{N}$ & 30 & 30 \\
\hline
\end{tabular}

Terdapat pengaruh antara financial attitude dengan financial behavior karena nilai signifikan pada uji chi square sebesar ,568 atau 56,8 persen. Peserta dengan sikap keuangan yang lebih baik cenderung lebih bijak perilaku keuangannya bila di bandingkan dengan mahasiswa pada tingkat sikap keuangan yang buruk.

Sikap keuangan berpengaruh dalam menentukan perilaku keuangan seseorang. Sikap keuangan mengarahkan seseorang dalam mengatur berbagai perilaku keuangannya. Dengan sikap keuangan yang baik maka seseorang akan lebih baik pula dalam pengambilan berbagai keputusan terkait manajemen keuangannya.

Seseorang dengan tingkat financial attitude baik akan menunjukan pola pikir yang baik tentang uang yaitu persepsinya tentang masa depan (obsesion), tidak menggunakan uang untuk tujuan mengendalikan orang lain atau sebagai penyelesai masalah (power), mampu mengontrol situasi keuangan yang dimiliki(effort), menyesuaikan penggunaan uang sehingga mampu mencukupi kebutuhan hidupnya (inadequancy), tidak ingin menghabiskan uang (retention), dan memiliki pandangan yang selalu berkembang tentang uang atau tidak berpandangan kuno (securities) sehingga akan mampu melakukan kontrol terhadap konsumsinya, mampu menyeimbangkan pengeluaran dan pemasukan yang dimiliki (cash flow), menyisihkan uang untuk tabungan dan investasi, serta mengelola hutang yang dimiliki untuk kesejahteraannya.

Hasil penelitian ini sejalan dengan penelitian yang dilakukan oleh Mien dan Thao (2015) terdapat hubungan yang signifikan antara sikap keuangan seseorang akan cenderung memiliki perilaku keuangan yang lebih bijak.

Beberapa foto kegiatan pelatihan perencanaan keuangan di Desa Semirejo 1 Kecamatan Tempuran adalah sebagai berikut: 


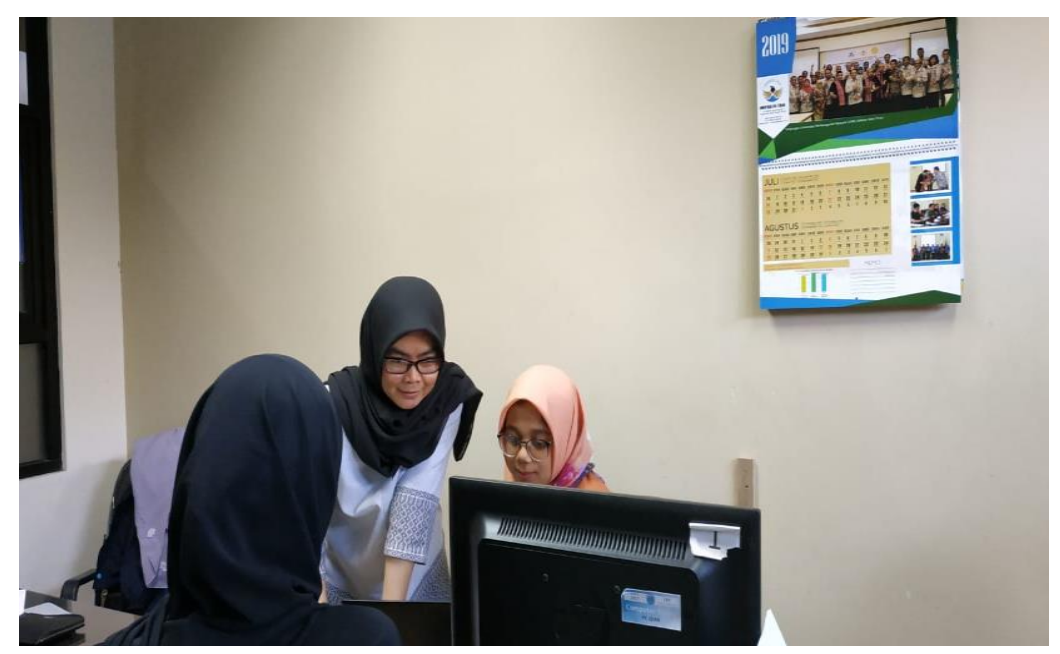

Gambar 1 Rapat Koordinasi Tim

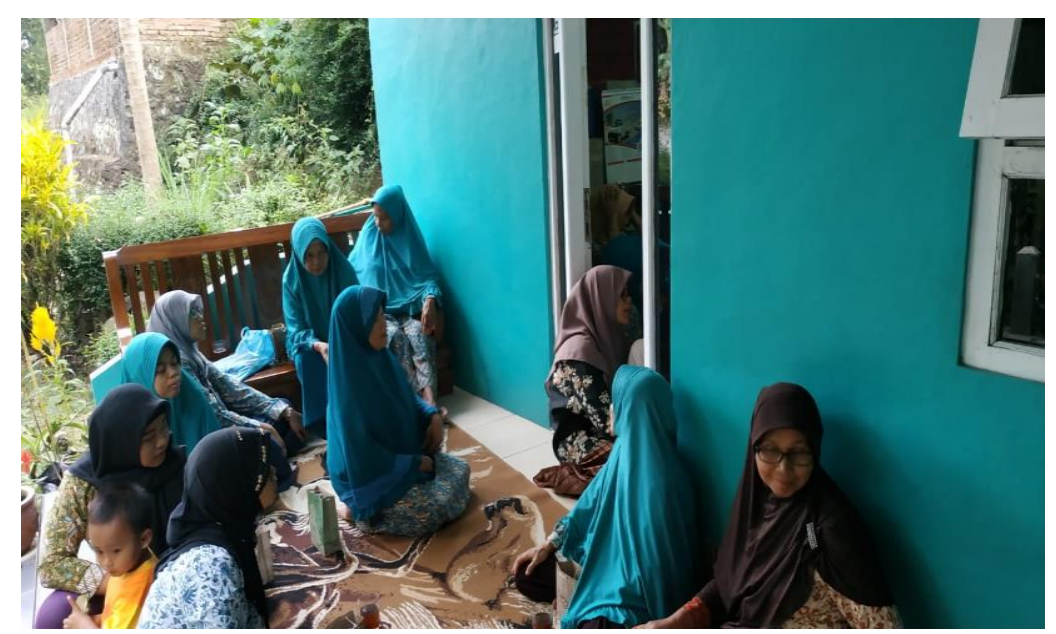

Gambar 2 Kegiatan Pelatihan Terhadap Peserta PKK

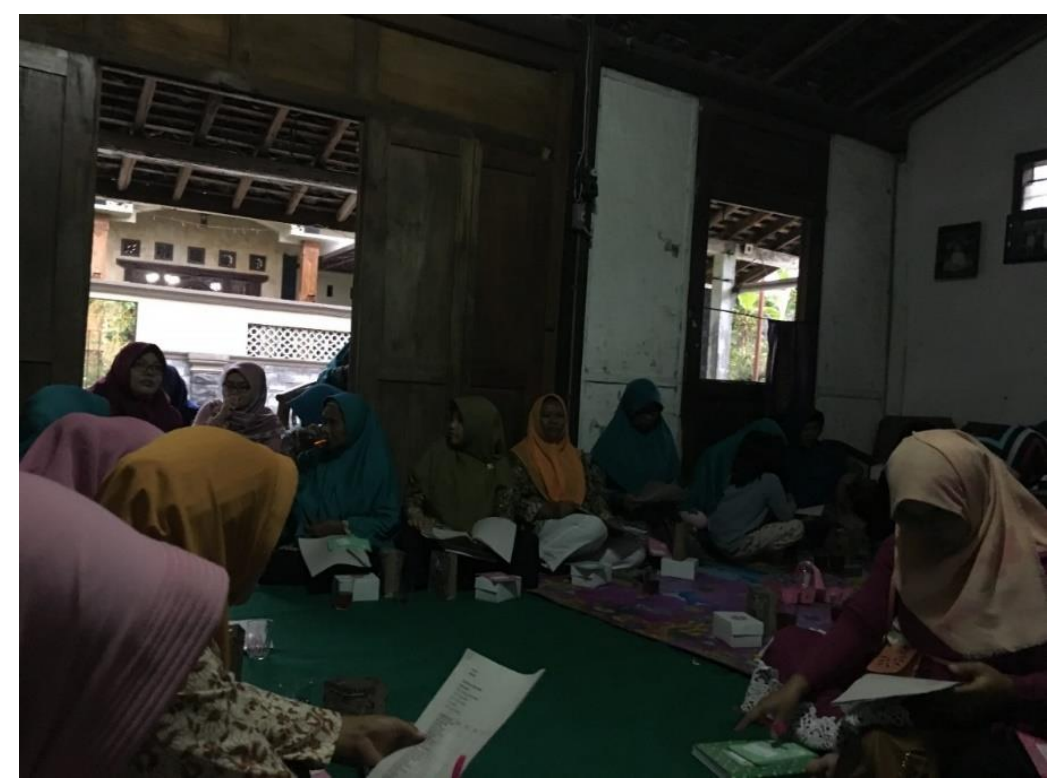

Gambar 3 Peserta Mengisi Kuisioner 


\section{Simpulan dan Rekomendasi}

Merencanakan keuangan keluarga itu penting agar mencegah terjadinya financial distress Atau kebangkrutan. Dengan pemahaman yang cukup baik tentang perencanaan keuangan keluarga maka rumah tangga dapat mengatasi masalahmasalah keuangan keluarga dengan solusi yang tepat. Peserta ibu-ibu PKK Desa Semirejo 1 masih perlunya pelatihan untuk perencanaan keuangan keluarga di berbagai lini melalui RT atau RW setempat bisa terus dilakukan. Hal ini akan mencegah terjadinya financial distress sehingga menuju kesejahteraan dan kemandirian keluarga. Berdasarkan pembahasan diatas maka didefenisikan kesimpulan sebagai berikut :

1. Peserta memahami mengapa perencanaan dan pengelolaan keuangan keluarga menjadi hal yang penting. Mereka menyadari tanpa perencanaan dan pengelolaan keuangan keluarga (apalagi pemisahan antara keuangan bisnis keluarga dan non bisnis keluarga) menjadi hal penting dalam keberlangsungan ekonomi atau berdirinya sebuah keluarga. Untuk melakukan perencanaan pengelolaan keuangan yang baik dan tidak hidup boros.

2. Peserta menyadari dan memahami road map ini sangat penting. Memang ada yang telah melakukan namun kebanyakan belum melakukan. Banyak dari mereka hanya mengikuti kehidupan saja, apa yang terjadi maka terjadilah. Namun mereka mulai sadar bahwa perencanaan dan pengelolaan keuangan keluarga bisa dilakukan sejak dini dan memiliki banyak manfaat dimasa depan.

3. Peserta memahami dan ingin mengaplikasikan siklus keuangan keluarga ini dimasa depan.

4. Peserta mereka merasa sulit untuk menabung dan berinvestasi karena sebagian besar merasa pendapatan mereka tidak cukup atau mampu untuk menabung dan investasi. Namun pematari meyakinkan bahwa untuk pengeluaran konsumsi harus yang dibutuhkan saja, jangan yang diinginkan. Peserta mulai memahami ternyata selama ini mereka membeli yang diinginkan bukan dibutuhkan.

5. Peserta (saat ini) tidak memperhitungkan kondisi di masa depan. Mungkin karena mereka (saat ini) mereka keluarga mereka aman aman saja. Namun mereka mulai menyadari pentingnya tabungan dan investasi untuk mengcover resiko dimasa depan, termasuk resiko / potensi berhentinya pembiayaan pendidikan dari anak anak mereka jika mereka tidak menyiapkannya sejak lebih awal atau dini.

6. Peserta memahami dan menyetujui untuk mulai pelan pelan mengalokasikan sebagian pendapatan mereka untuk investasi.

7. Peserta memahami akan berkeinginan untuk menerapkan prinsip prinsip dasar investasi ini didalam perencanaan dan pengelolaan keuangan keluarga mereka.

8. Peserta terkadang membuat catatan catatan penerimaan dan pengeluaran namun tidak menghitung kekayaan bersih saat ini. Namun dengan model sederhana yang diberikan pemateri maka mereka memahami cara sederhana membuat laporan kekayaan bersih (neraca sederhana) dan cash flow sederhana (rugi laba). 


\section{Daftar Pustaka}

Andrrew Vincentius, Linawati Nanik.2014. hubungan faktor demografi dan pengetahuan keuangan, dengan Perilaku Keuangan Karyawan Swasta di Surabaya, FINESTIA Vol. 02, No. 02:35-39

Fuaida, Lisma Dyawati. 2009. Manajemen keuangan keluarga miskin: studi kasus mitra program masyarakat mandiri, dompet dhuafa Republika.

Furnham, A.1984. Several Sides of the Coin: The Science of Cash Usage. Temperament and Variations, 5: 501:509.

Hidayat, Taufik (2010). Money Planning:Mengelola \& Merencanakan Keuangan Pribadi dan Keluarga. Jakarta Selatan: Mediakita.

Hilgert,Marianne A., Jeanne M.Hogarth dan Sondra Baverly.2003. Family Financial Management : The Affiliation between Information and Behavior.Federal Reserve Bulletin,89(7):309-322.

Henry Faizal Noor 2009. Investasi, Pengelolaan Keuangan Bisnis,dan Pengembangan Ekonomi Masyarakat,Jakarta: Indeks.

Ida dan Chintia Yohana Dwinta.2010. Pengaruh locus of management, money information, dan financial gain terhadap money management behavior. JurnalBisnis dan Akuntansi, Vol. 12, No. 3: $131-144$.

Mankiw, N Gregory .2003. Pengantar Ekonomi, Edisi ke-2 Jilid 2, Jakarta:Erlangga.

Sina, Peter Garlans.2014. Tipe Kepribadian Dalam Personal Finance. Jurnal JIBEKA Volume 8 No $1: 54-59$.

Stoner, James A.F., Daniel R. Gilbert, R. Edward Freeman. 2009.Management. 6th Edition. New York: Pe

Xiao, J. J., Shim, S., Barber, B., \& Lyons, A. 2007. Financial behavior and quality of life of college students: Implications for college financial education. Proceedings of Association for Financial Counseling and Planning Education: 33-43. 